Structural Component of the Constitutional and Legal Status of Judges in Ukraine. The article is devoted to the analysis of the Ukrainian and foreign constitutional legislation on the judicial system and the status of judges in terms of the requirements for legal education and professional experience. The key findings of the research argue that the study of the nature of the constitutional and legal status of judge institute is not possible without characterization of its constituent elements. Until recently, the requirements for legal education and professional experience in the constitutional law science lack theoretical grounding. The analysis shows that the current wording of Part 3 of Article 127 of the Constitution of Ukraine takes into account the positive foreign experience and, in general meets the European democratic standards, and the constitutional provisions are specified in the relevant special law. The requirement for legal education and professional experience is an additional (non-core) element of the judge's legal status as it affects the scope of his rights and responsibilities. In addition, the requirement for legal education and professional experience of candidates for judicial office is conditioned by the need to guarantee for the individuals and legal entities impartial, objective and timely justice, provided by qualified judges with the proper level of professional training. The author believes, that increasing the length of professional experience in the field of law from three to five years is necessary for a more thorough mastery of professional knowledge, skills and abilities that are necessary for the administration of justice. However, the using of the category «area of the law» in the classification of professional legal activities creates certain complications due to its generality, and therefore its official interpretation is necessary.

Key words: constitutional and legal status of judges; legal status of judges; professional experience as required by legal education and professional experience; judge; legal education.

УДК 34:061.1 ЄС

DOI https://doi.org/10.32782/2409-4544/2019-2/12

О. Юхимюк

\title{
Функції принципів права Європейського Союзу в практиці Суду Європейського Союзу
}

У статті проведено функціональний аналіз принципів права Європейського Союзу в практиці Суду Європейського Союзу. Досить загальний вміст норм права Європейського Союзу, їх повна або часткова відсутність призводять до зростання значення принципів права в практиці Суду Європейського Союзу. Принципи права Європейського Союзу в практиці Суду Європейського Союзу реалізують ряд завдань, до яких зокрема належать: заповнення прогалин у праві Свропейського Союзу; інтеграція правової системи Свропейського Союзу у цілому, правових систем країн-членів Європейського Союзу, а також країн, що прагнуть до членства в Європейського Союзу; установча функція, яка полягає у формуванні окремої правової наднаціональної системи Європейського Союзу. Принципи права Європейського Союзу в практиці Суду Європейського Союзу виступають додатковим, але не другорядним інструментом тлумачення і застосування установчих договорів Європейського Союзу; забезпечення і захист прав людини, формування інституту громадянства Європейського Союзу. Саме принципи права виступають засобом заповнення прогалин як у правозастосовчій діяльності інститутів Європейського Союзу, так і безпосередньо в практиці Суду Справедливості. Завдяки принципам права можуть вирішуватися питання, не врегульовані правом Європейського Союзу, що, однак не означає можливості Суду Справедливості механічно посилатись на принципи права держав-членів. Створюючи і застосовуючи принципи права, Суд Справедливості фактично реалізує квазі-гармонізацію, яка не лише зближує правові системи держав-членів Європейського Союзу, але й країн, що прагнуть до членства в Європейському Союзу. Принципи права також є інструментом не лише застосування, а й належного розуміння і тлумачення права Європейського Союзу. Принципи права мали й матимуть надалі винятковий вплив на доктрину права Європейського Союзу, зокрема принципи верховенства права, недискримінації та інші.

Ключові слова: принципи права, принципи права Європейського Союзу, Суд Справедливості Європейського Союзу.

(С) Юхимюк О., 2019 
Постановка наукової проблеми та ії значення. Базовим імпульсом функціонування різноманітних судів виступає потреба забезпечення найбільшої ефективності правового регулювання, в той час як основною роллю судів $\epsilon$ вирішення конфліктів. Часто саме судді першими викривають існуючі проблеми у правовому регулюванні, для вирішення яких немає відповідей в чинному праві. Суд стає своєрідним містком між правом та реальними суспільними відносинами, перетворюючи право формальне в право дієве. Особлива інституційна структура Європейського Союзу та аксіологічний вимір іiї права зумовлюють необхідність прийняття судових прецедентів. Враховуючи відносно нетривалу правову традицію Європейського Союзу (в тому числі Європейських Співтовариств) Суду Свропейського Союзу відводиться особлива роль у формуванні відповідного правопорядку.

Реалізація цілей Європейського Союзу, визначених відповідними договорами, досягається не лише правовими актами, виданими відповідними інституціями в межах їх компетенції, а й за допомогою інструментів менш формалізованих, деталізованих, обов'язкових, спрямованих на чітко визначене коло адресатів. Досить загальний зміст норм права СС та їх повна чи часткова відсутність спричиняють зростання значення принципів права у практиці Суду Свропейського Союзу.

Аналіз досліджень цієї проблеми. Проблемами принципів права в Україні та в країнах ЄС приділяли увагу такі вчені, як Л. Ентін, В. Кернз, В. Опришко, А. Омельченко, А. Татам, А. Фастовець, П. Рабінович, А. Колодій, В. Колесниченко та ін. Разом з тим формування загальної картини творення системи принципів права ЄС сприятиме більш комплексному і грунтовному розумінню тих правових форм, за допомогою яких здійснюється правове регулювання інтеграційних процесів у рамках $\mathrm{CC}$.

Мета й завдання статті. Дослідження системи принципів права Європейського Союзу у функціональному аспекті не була предметом самостійних наукових розвідок. Саме тому, виникнення та формування системи принципів права $\mathrm{CC}$ варто розглядати у нерозривному зв'язку 3 функціонуванням Суду Європейського Союзу. Наведене вище зумовлює мету статті - крізь призму узагальненого аналізу наукової літератури дослідити розвиток та формування системи принципів права в практиці Суду Європейського Союзу.

Виклад основного матеріалу й обгрунтування отриманих результатів дослідження. Все частіше в літературі домінує думка про визнання рішень Суду Європейського Союзу джерелом вторинного права ЄС. Підтвердженням цього є позитивне ставлення до правотворчої діяльності Суду ЄС. Відповідно до ч. 1 ст. 19 Лісабонського договору 2007 року Суд Європейського Союзу забезпечує дотримання законодавства у тлумаченні та застосуванні Договорів [1].

Спочатку він був утворений як єдина установа. В процесі організаційних змін 1988 року його перетворено на дворівневу структуру: Суд першої інстанції і суд вищого рівня, за яким збережено попередню власну назву судового органу - Суд Свропейського Союзу. На сьогоднішній день Суд Європейського Союзу складається з трьох установ: безпосередньо Суду (Суду Справедливості), Суду загальної юрисдикції та спеціалізованих судів [2, с. 87].

Така судова побудова була актуальною до вересня 2016 р., а після вересня у зв’язку із зростанням кількості позовів до Загального суду та надмірною тривалістю їх розгляду, Рада ЄС та Парламент вирішили значно збільшити кількісний склад Загального суду (з 28 суддів до 56) та передати йому юрисдикцію Трибуналу з питань цивільної служби $Є С$, який припинив свою діяльність 1 вересня 2016 р. Тож зараз, незважаючи на можливість створення спеціалізованих судів, судова система СС залишається дволанковою [3, с. 51].

Особливо на початковому етапі існування Суду суди держав-членів звертались до нього 3 проханням видання рішень, які згодом сприяли заповненню прогалин в праві та формуванню принципів, що в подальшому стали основою правового порядку Європейського Союзу. Тож перед Судом постало завдання заповнення прогалин шляхом формування принципів, здатних стати основоположними в правовому поряду спільноти. Для досягнення цієї мети судді Суду мали б напрацювати власну концепцію тлумачення права спільноти.

Для правопорядку спільноти, що перебував у стані формування, основоположними стали справи Van Gend en Loos [4] (установлено один з найважливіших принципів - принцип безпосередньої дії права ЄC), Costa v. ENEL [5] (принцип верховенства права ЄC) та ін. Саме на власні рішення, в яких містились принципи права, ССЄС посилався в подальшому при вирішенні аналогічних справ. Формуючи принципи права, Суд Справедливості впливав не лише на формування права спільнот, але й на процес європейської інтеграції та правопорядок держав-членів. Адже вплив на застосування національними судами держав-членів права Європейського Союзу має не лише формальна 
обов'язковість рішень Суду Європейського Союзу, але й верховенство права ЄС над національним правом.

Суд Справедливості Європейського Союзу не дав однозначної відповіді на питання про походження принципів права, визнаючи іноді їх частиною існуючого права, якого необхідно дотримуватись (наприклад, справа Stauder, в якій Суд ЄС встановив, що принцип поваги до прав людини є частиною загальних принципів права Співтовариства і захищається Судом [6]), а іноді такими, що формуються в ході здійснення правосуддя (наприклад, справа Algera, в якій суд встановив принцип захисту легітимних очікувань, спрямований на реалізацію контролю за діяльністю публічної адміністрації, охорону прав індивідів та забезпечення відповідальності державних органів і посадових осіб за прийняті ними рішення [7]).

В цілому, як зазначається в літературі, загальні принципи права СС мають двояке застосування. По-перше, вони виступають основою для ефективного функціонуванння правової системи ЄС. По-друге, загальні принципи права ЄС сприяють усуненню багатьох прогалин в тлумаченні права ЄС. Суд СС неодноразово підкреслював у своїх рішеннях особливе значення загальних принципів права ЄС серед джерел права ЄС в процесі вирішення прогалин в праві ЄС [8, c. 45].

Звісно, обов’язок формального закріплення принципів права СС покладається на правотворчі органи співтовариств, але в разі відсутності відповідної активності з боку правотворців, по суті на ССЄС покладається завдання наповнення змістом принципів права СС та забезпечення їх дотримання і належного тлумачення.

В справі Parti écologiste «Les Verts» v. European Parliament Суд Справедливості проаналізував юридичну природу договорів про заснування Європейських спільнот та дійшов висновку, що ці договори становлять собою своєрідну «конституційну хартію» $Є С$, що має тлумачитись та застосовуватись в такий спосіб, що не обов'язково відповідатиме загальним правилам тлумачення міжнародних договорів [9]. 3 цього ж рішення випливає засада інституційної рівноваги, яка передбачає, що як і держави-члени, так і інституції є суб'єктами судового контролю в питанні відповідності вживаних ними заходів «конституційній хартії».

При тлумаченні права Судом Справедливості більш ефективним методом вбачається метод порівняння правових систем держав-членів. Принципи права переважно належать до неписаного права, незважаючи на те, що містяться в рішеннях Суду Справедливості, який часто на них посилається. Деякі принципи права частково знайшли своє відображення і договорах, на основі яких функціонує Європейський Союз (наприклад, принципи субсидіарності та пропорційності, передбачені ст. 5 Договору про Європейський Союз [10]), і протоколах до них (наприклад, Протокол (№ 2) Про застосування принципів субсидіарності та пропорційності [10]).

Науковці пропонують загальні принципи права Європейського Союзу ділити на три групи. Перша категорія включає в себе загальні принципи права, притаманні всім або більшості правових систем країн-членів ЄС. Існування таких принципів знаходить своє відображення в ст. 340 (2) Договору про функціонування Європейського Союзу [10], де зазначається, що у разі позадоговірної відповідальності Союз згідно з загальними принципами, що є спільними для законодавств державчленів, відшкодовує всі збитки, завдані його установами або службовцями під час виконання їхніх обов' язків. На практиці Суд Справедливості неодноразово враховував законодавство країн-членів ЄС при тлумаченні права ЄС. Такі загальні принципи права ЄС, як захист права власності, преюдиційна судова процедура, принцип «естопель» були запозичені Судом СС у правових системах країн-членів ЄС. Проте, варто підкреслити, що Суд ЄС залишає за собою право вибору окремих принципів, притаманних правовим системам країн-членів $\mathrm{CC,} з$ метою визнання їх загальними принципами права ЄC. Інакше кажучи, Суд $\mathrm{CC}$ може обрати і визнати будь-який принцип, притаманний правовій системі будь-якої, навіть однісї країни-члена СС, як загальний принцип права СС. Більше того, зміст такого принципу в тому сенсі, в якому він використовується в окремій країні-члені ЄС, може відрізнятись від змісту, що надається йому Судом ЄС [8, с. 46].

До другої категорії загальних принципів права ЄС належать принципи міжнародного права. Суд СС посилається на принципи міжнародного права в разі їх обов'язковості для країн-членів ЄС. Як i попередньому випадку, Суд СС користується виключною компетенцією визначення змісту принципів міжнародного права при визнанні їх загальними для правової системи ЄС. Лісабонський договір посилює роль принципів міжнародного права в правовій системі $€ С$ [8, с. 47]. Після його вступу в дію стаття 3 (5) Договору про СС доповнилась положенням: «У своїх відносинах зі світом Союз підтримує та поширює свої цінності та інтереси, сприяє захисту своїх громадян. Союз підтримує мир, безпеку та сталий розвиток планети, солідарність та взаємну повагу народів, вільну справедливу 
торгівлю, викорінення бідності та захист прав людини, зокрема прав дитини, а також суворе дотримування й розвиток міжнародного права, зокрема дотримання принципів Статуту ООН» [10]. В Хартії основних прав Свропейського Союзу, яка набрала юридичної сили після введення в дію Лісабонського договору, зазначається, що «Європейський Союз заснований на неподільних i загальних цінностях - гідність людини, свобода, рівність, солідарність; він спирається на принципи демократії і правової держави» [11].

До третьої категорії загальних принципів права ЄС належать принципи, які закріплені в установчих договорах ЄС (принцип субсидіарності, заборона дискримінації) [8, с. 47-48].

Висновки. Отож, принципи права Європейського Союзу в практиці Суду Свропейського Союзу реалізують ряд завдань, до яких зокрема належать: заповнення прогалин в праві СС; інтеграція правової системи $Є С$ вцілому, правових систем країн-членів $Є С$, а також країн, що прагнуть до членства в СС, виступають партнерами СС; установча функція, яка полягає у формуванні особливої правової наднаціональної системи СС; виступають додатковим, але не другорядним інструментом тлумачення та застосування установчих договорів $\mathrm{CC}$; утвердження і захист прав особи, формування інституту громадянства $€$ С.

Завдяки принципам права можуть вирішуватися питання, не врегульовані правом Європейського Союзу, що, однак не означає можливості Суду Справедливості механічно посилатись на принципи права держав-членів. Створюючи і застосовуючи принципи права, Суд Справедливості фактично реалізує квазі-гармонізацію, яка не лише зближує правові системи держав-членів СС, але й країн, що прагнуть до членства в Свропейському Союзу.

Прогалини в праві $€$ неминучими для будь-якої правової системи, правова система Свропейського Союзу не виключення. Тож саме принципи права виступають засобом їх заповнення як в правозастосовчій діяльності інституцій $Є С$, так і безпосередньо Суду Справедливості. Вони по суті $\epsilon$ посередниками між національними правовими системами та правовою системою $\mathrm{CC}$, покликаними уніфікувати ці системи. Принципи права також є інструментом не лише застосування, а й належного розуміння і тлумачення права Європейського Союзу. Принципи права мали й матимуть надалі винятковий вплив на доктрину права $€ \mathrm{C}$, зокрема принципи верховенства права, недискримінації та інші. Досить загальний зміст норм права ЄС та їх повна чи часткова відсутність спричиняють зростання значення принципів права у практиці Суду Справедливості Європейського.

\section{Джерела та література}

1. Treaty amending the Treaty on European Union and the Treaty establishing the European Community // Councilofthe European Union [Electronic resource]. - Access mode: http://consilium.europa.eu/cms3_fo/showPage.asp?id=1317\&lang=en.

2. Юхимюк О. Використання філологічного способу тлумачення права Судом Справедливості Європейського Союзу / О. Юхимюк // Науковий вісник Ужгородського національного університету. Серія «Право». - 2013. - Випуск 22. - Ч. 1. - С. 87-89.

3. Комарова Т. В. Суд Свропейського Союзу: розвиток судової системи та практики тлумачення права СС: монографія / Т. В. Комарова. - Харків: Право, 2018. - 528 с.

4. Case C-26/62 Van Gend en Loos v. der Belastingen Administration of February 5, 1963 // European Court Reports. -1963.

5. Case C-6/64 Costa v. E.N.E.L. of July 15, 1964 // European Court Reports. - 1964.

6. Case C-29/69 Stauder v. Stadt Ulm of November 12, 1969 // European Court Reports. - 1969.

7. Joined Cases 7/56\& 3-7/57 Algera and others v Common Assembly [1957] [Electronic source]. - Access mode: http://eur-lex.europa.eu/LexUriServ/LexUriServ.do?uri=CELEX:61956CJ0007:EN:HTML.

8. Петров Р. А. Транспозиция «асquis» Европейского Союза в правовые системы третьих стран: монография / Р. А. Петров. - К.: Истина, 2011. - 384 с.

9. Case 294/83, (Parti écologiste «Les Verts» v. European Parliament), Judgment of 23rd April 1986, ECR [Електронний ресурс]. - Режим доступу: http://eurlex.europa.eu/LexUriServ/LexUriServ.do?uri= CELEX:61983J0294:EN:HTML,P.1365.

10. Консолідовані версії Договору про Європейський Союз та Договору про функціонування Європейського Союзу з протоколами та деклараціями [Електронний ресурс]. - Режим доступу: https://zakon.rada.gov.ua/laws/show/994_b06

11. Хартія основних прав Європейського Союзу [Електронний ресурс]. - Режим доступу: https://zakon.rada.gov.ua/laws/show/994_524 
Юхимюк А. Функции принципов права Европейского Союза в практике Суда Европейского Союза. В статье проведен функциональный анализ принципов права Европейского Союза в практике Суда Европейского Союза. Достаточно общее содержание норм права Европейского Союза, их полное или частичное отсутствие приводят к росту значения принципов права в практике Суда Европейского Союза. Принципы права Европейского Союза в практике Суда Европейского Союза реализуют ряд задач, к которым в частности относятся: заполнение пробелов в праве Европейского Союза; интеграция правовой системы Европейского Союза в целом, правовых систем стран-членов Европейского Союза, а также стран, стремящихся к членству в Европейского Союза; учредительная функция, которая заключается в формировании отдельной правовой наднациональной системы Европейского Союза. Принципы права Европейского Союза в практике Суда Европейского Союза выступают дополнительным, но не второстепенным инструментом толкования и применения учредительных договоров Европейского Союза; обеспечение и защита прав человека, формирования института гражданства Европейского Союза. Именно принципы права выступают средством заполнения пробелов как в правоприменительной деятельности институтов Европейского Союза, так и непосредственно в практике Суда Справедливости.

Ключевые слова: принципы права, принципы права Европейского Союза, Суд Справедливости Европейского Союза.

Yukhymiuk O. The Functions of the European Union Law Principles in the Court of Justice of the European Union Practice. The article presents the results of the functional analysis of the fundamental principles of the European Union Law in the practice of the Court of Justice of the European Union. The lack of specificity and general nature of the content of the norms of European Union law, their complete or partial absence, lead to an increase in the importance of the principles of law in the practice of the Court of Justice of the European Union. The principles of the European Union law in practice of the European Union Court of Justice facilitate a solution of a number of problems and tasks, which in particular include: filling in gaps in European Union law; the integration of the European Union legal system as a whole and the legal systems of European Union Member States, and those aspiring to European Union membership; formation of independent supranational European Union legal system. These principles act as an additional, but not a minor, tool for interpreting and applying the founding treaties of the European Union, protecting human rights, and promoting the formation of an European Union citizenship institute. It is these principles of law that serve as a means of filling the gaps in the law enforcement activities of the European Union institutions and directly within the Court of Justice. The principles of law may deal with matters not governed by European Union law, which, however, does not mean that the Court of Justice can mechanically refer to the principles of the law of the Member States. Creating and applying the principles of law, the Court of Justice effectively implements quasi-harmonization, which not only brings together the legal systems of the European Union Member States, but also of the countries aspiring to membership in the European Union. The principles of law are also a tool not only for the application but also for the proper understanding and interpretation of European Union law. The principles of law have and will continue to have an exceptional impact on the doctrine of European Union law, in particular the principles of the primacy of law, nondiscrimination and others.

Key words: principles of law, principles of European Union law, European Union Court of Justice. 